\title{
THE CHILLING EFFECT AND THIS MOST ANCIENT FORM OF VENGEANCE: DISCRIMINATION AND VICTIMISING THIRD PARTIES
}

\begin{abstract}
The recent Equality Act 2010 includes a revised definition of "victimisation", which (in the Act's most litigated field of employment) prohibits employers from victimising workers who use the legislation. The underlying mischief should be the deterrent effect upon litigants, or potential litigants (the "chilling" effect). One particularly pernicious deterrent is the victimisation, not of the complainant, but of a third party, such as the complainant's spouse, loved one, or friend, "the most ancient form of vengeance". Yet the revised definition does not address the deterrent effect per se, and specifically excludes third party victimisation from its reach.

This paper explores, first, why the deterrent mischief and the chilling effect should underpin the victimisation provision, so that it addresses third party victimisation, second, the potential of existing alternative solutions in domestic law; and third, the position EU law, and under the United States' Civil Rights Act 1964. It concludes that the best existing solution lies in EU general principles, but for the sake of certainty, a simple amendment to the existing formula is required, which would solve the problem without any undue side-effects.
\end{abstract}

\section{INTRODUCTION}

At the end of the movie Spartacus, the Romans famously threaten to crucify all their captured slaves unless Spartacus gives himself up. This threat persuaded the hero to concede defeat and save his comrades. As he begins to stand, Spartacus is saved by the loyalty of his fellow slaves, each of whom declares: "I am Spartacus!" The point - for the present purpose - is that Spartacus was moved to give up his life by a threat to others with whom he had empathy. In this case there was a bond of comradeship. In others, the emotional exploitation uses spouses or civil partners, family, loved ones, close friends, or even work colleagues. The most commonly litigated area of discrimination law is the field of employment. Of course, one would not expect to find such dramatic threats in the field of employment discrimination. But in principle, the practice exists, as characterised by Richard A. Posner: "To retaliate against a man by hurting a member of his family is an ancient method of revenge, and is not unknown in the field of labor relations". 1

In the field on employment, many scenarios involving this "third party victimisation" could arise. Most can be grouped into three Classes, as shown here.

A worker issues discrimination proceedings against her employer (the "protected act") and:

Class No. 1: Same employer - same workplace.

In retaliation, the employer fires the worker's fiancé (who worked in the same undertaking).

Variations on this would be that the retaliation falls short of dismissal (e.g. rejecting a promotion application, withholding an expected pay rise, giving a poor appraisal), or that the victim is the claimant's spouse or civil partner, relative, loved one, close friend, or a work colleague.

No. 2: Same employer - different undertaking. As above, save that the fiancé worked for another undertaking owned or managed by the same employer.

No. 3: Different employer. As above, save that the fiancé worked for an undertaking owned or managed by a friend or relative of the employer, who fired him on the say-so of the employer, or out of tacit sympathy.

In these scenarios, the employer's action would deter the claimant and other workers (the "chilling" effect) from using the discrimination legislation.

The recent Equality Act 2010 includes a revised definition of "victimisation" (see below), which prohibits employers from victimising workers who use the legislation. The mischief here should be the deterrent effect upon the complainant and the chilling effect. Yet the revised definition was not drafted with this mischief in mind, and it specifically excludes third party victimisation from its reach. The exclusion of this particularly pernicious form of victimisation leaves the statute open to abuse by employers, who may carefully (or in some cases, instinctively), target the complainant's spouse or civil partner, relative, loved one, close friend, or work colleague.

This paper, first, argues that the mischief of deterrents and the chilling effect should inform the primary purpose of the victimisation provision, and in doing so, it should cover third party victimisation. The argument 
uses EU case law and legislative history of the equality Directives, the case law of United States Civil Rights Act 1964, and by way of analogy, criminal contempt of court. Second, it evaluates the potential of existing alternative solutions in domestic law. Third, it explores the approach towards third party victimisation itself, in the EU equality Directives, the ECJ and its various international influences, including the United States. It concludes that the best existing solution lies in EU general principles, but for the sake of certainty, a simple amendment to the existing formula is required, which would solve the problem without any undue side-effects.

\section{THE DOMESTIC LEGISLATION}

The shortcoming of the revised victimisation provision is apparent in the wording:

Equality Act 2010

27 Victimisation

(1) A person (A) victimises another person (B) if A subjects B to a detriment because-

(a) B does a protected act, or

(b) A believes that B has done, or may do, a protected act.

The "protected acts" comprise bringing or supporting proceedings, making allegations, or "doing any other thing" under or in connection with the Act. Giving false evidence or information, or making a false allegation, is not a protected act if it was done in bad faith.

For liability, it is necessary that (1) that the claimant has done a protected act (or the defendant believes he has, or will do it), (2) the defendant subjected the claimant to a detriment (3) because the claimant did the protected act. This formula fails to address the mischief in (at least) two ways. First, it requires harm ("detriment") to the victim, which rules out cases where the employer's act in the event did not harm the victim, but still sent out a signal to others not the complain, and so had a chilling effect. This could happen where an employer supplies a negative, or no, reference, that in the event did not affect the victim's job prospects. ${ }^{2}$ Second, and critical to the present context, the first element specifies that the person victimised must be the person who did the protected act, $^{3}$ thus specifically excluding third party victimisation from its reach.

\section{THE DETERRENT MISCHIEF, THE CHILLING EFFECT, AND VICTIMISATION}

The obvious initial question is whether the deterrent effect should be central to the victimisation provision. The victimisation provision operates on an individualistic basis, although tribunals may now provide broader remedies affecting the whole workforce. ${ }^{4}$ This does not mean necessarily that it has no broader purpose. One would logically and instinctively consider that it should remove the fear of using the legislation: the deterrent effect. It does so by dissuading the employer from victimising anyone using it. Assuming this is so, those deterred would comprise any worker who became aware of their employer's willingness to victimise (perhaps evidenced by an act of actual or threatened victimisation of a colleague). The fear, if anything, is deepened if the threat is to a spouse or civil partner, relative, loved one, close friend, or even a work colleague. Where the threat in the event does not harm the claimant, or fails to deter an exceptionally robust complainant, it might still deter others. This is where the chilling effect, in itself, becomes important. Thus, if the mischief addressed by the victimisation provision were the deterrent effect, the provision should include the chilling effect and third party victimisation.

In support of this, there are three legal indicators suggesting that the deterrent mischief should underpin the notion of victimisation in employment discrimination law. These can be found in EU law (the jurisprudence of the ECJ and the history of the equality Directives), the US Civil Rights Act 1964, and by analogy with contempt of court.

\section{(i) EU Law}

First, the history of the victimisation provisions in the equality Directives ${ }^{5}$ can be traced to the ECJ judgment in Coote $v$ Granada. ${ }^{6}$ The original sex discrimination Directive, the Equal Treatment Directive 76/207/EEC, did not, except for one specified instance (dismissal as a reaction to bringing a claim, Article 7), expressly outlaw victimisation. However, it was held that victimisation cases falling outside Article 7 could succeed under the general ambition of Article 6, which provided that member states should "introduce into their national legal systems such measures as are necessary to enable all persons who consider themselves wronged by failure to apply to them the principle of equal treatment ... to pursue their claims by judicial process ...". In this case, following her dismissal for pregnancy, Mrs Coote sued her employer. Subsequently, and after those proceedings were dead, the employer refused to provide her a job reference and Mrs Coote sued again, this time for victimisation. The issue was whether Article 6 covered retaliation against former employees. The ECJ found for Ms Coote, stating:

The principle of effective judicial control laid down in Article 6 ... would be deprived of an essential part of its effectiveness if the protection which it provides did not cover measures ... as in ... this case... . Fear of such measures, where no legal remedy is available against them, might deter workers who considered 
themselves the victims of discrimination from pursuing their claims by judicial process, and would consequently be liable seriously to jeopardise implementation of the aim pursued by the Directive. ${ }^{7}$

The policy supporting this decision, expressed in the second sentence, goes beyond the facts of Coote, and suggests that any retaliation that might deter workers from using the discrimination legislation should be unlawful. Further, as Mrs Coote's proceedings were concluded, the employer's act could not have deterred her. The only people possibly deterred in this case were others. Thus, the chilling effect, rather than harm to the individual, is the principal mischief identified by the Coote judgment.

Some broader, less specific sentiments can be found in the legislative history to the equality Directives. The European Commission stated that the protection against victimisation in the Race Directive 2000/43/EC was "a crucial element in allowing individuals to assert their rights", 8 and when advancing the role of equality bodies it stated that "many victims of discrimination do not proceed to court with their complaints because of the cost and for fear of victimisation". 9 In relation to the Framework Directive 2000/78/EC, the Commission expressed similar concern about victimisation, although appeared to envisage that the principal complainant and victim were the same person: "Effective legal protection must include protection against retaliation. Victims may be deterred from exercising their rights due to the risk of retaliation. Since fear of dismissal is generally one of the major obstacles to individual action, it is necessary to protect individuals against dismissal or other adverse treatment ...". 10

Although not expressed in terms, this suggests that at a European level, the deterrent effect (and with it the chilling effect) underpins the victimisation provisions. This being the case, the failure to specify third party victimisation appears to be an oversight rather than a deliberate exclusion.

\section{(ii) US Civil Rights Act 1964}

Concerns about access to justice, deterrents, and the chilling effect are apparent in United States case law under Title VII ("Employment") of the Civil Rights Act 1964. In Robinson v Shell ${ }^{11}$ the Supreme Court stated that a primary purpose of the victimisation provisions is "Maintaining unfettered access to statutory remedial mechanisms" and consequently held that the threat of post-employment retaliation would deter victims of discrimination from complaining. ${ }^{12}$ This "fear of deterrent" purpose was presumed to include fear by other workers in Hashimoto $v$ Dalton. ${ }^{13}$ Here, the Ninth Circuit held that the provision of a negative job reference in retaliation, which in the event did not affect the claimant's job prospects, remained an actionable act of victimisation because of "the chilling effect which [the] ... retaliatory conduct might have on the remaining employees"14 The remedy was costs and a remedial order, but not damages. ${ }^{15}$

\section{(iii) Contempt of Court}

There are inescapable parallels with contempt of court for interfering with the administration of justice, and some principles there comfortably could apply to victimisation. ${ }^{16}$ Those who intimidate litigants or witness are liable to prosecution for common law ${ }^{17}$ (criminal) contempt. Contempt proceedings are normally brought by the AttorneyGeneral, ${ }^{18}$ and it seems, only where the intimidation is serious. This might explain why no contempt proceedings have brought (yet) in relation to a discrimination complaint, although this could be because of a (misplaced) belief that all forms of victimisation is provided for by the Equality Act. ${ }^{19}$

The High Court or Court of Appeal is empowered to punish for contempt where the contempt is in connection with employment tribunal proceedings. ${ }^{20}$ The Criminal Justice and Public Order Act 2001, s.39, introduced a statutory variety of contempt, making it an offence to intimidate a witness (which includes the claimant) in civil proceedings. The intimidation can include a threat to the person, his property, finances, or otherwise, or any statement. ${ }^{21}$ Notably in this context, section 39(2)(b) provides that it is immaterial "whether that [intimidating] act is done to the victim himself or to another person...". In $R v$ Sahin, ${ }^{22}$ the Court of Appeal stated obiter that a threat to harm a litigant's grandmother unless she dropped the case (of family proceedings and a nonmolestation order) would "inevitably" lead to a conviction under s.39. ${ }^{23}$ This mirrors the parallel provisions for criminal trials in the Criminal Justice and Public Order Act 1994, s.51. It was said of the similarly-worded earlier version of $\mathrm{s} .51(3)$ :

\footnotetext{
"“... subsection (3) extends the offence to intimidating a third party where it is intended to intimidate the person concerned' - i.e. the witness. - 'It appears that this provision was intended to apply to threats to friends and families of the protected groups' that is to say, those assisting in criminal investigations, to witnesses and to jurors. It deals with cases where the intimidation of a witness is achieved by threats to others, say, his family". 24
} 
Neither sections 30 nor 51 apply to proceedings in an employment tribunal; ${ }^{25}$ their usefulness here is to show that the law treats intimidation of litigants (and witnesses) seriously, and it makes no difference whether the act or threat is directed at the litigant or a third party. Quite obviously, the law of contempt is concerned with deterrents to people enforcing their legal rights, and would just as readily punish threats or harm to third parties in this cause.

ECJ authority, the legislative history of the equality Directives, US Civil Rights Act case law, and the parallel offence of contempt of court, all suggest that the deterrent mischief, and in particular the chilling effect, should underpin actions for victimisation provided by the Equality Act 2010. As such, the law of victimisation should protect third parties.

\section{ALTERNATIVE SOLUTIONS IN DOMESTIC LAW}

Before searching for a solution with the law of victimisation, there a number of existing alternative solutions to consider, if only to eliminate them from this inquiry.

\section{A. Principal Complainant Sues}

\section{(i) Damages}

In many of these scenarios, the principal complainant may have grounds to sue for victimisation. For instance, if a part-time secretary's complaint of sexual harassment results in the dismissal of her full-time husband, it is likely she would suffer some financial loss in consequence. Further, she may suffer injury to her feelings for the emotional distress caused by her husband's dismissal. In any case, she suffers a detriment at the hands of her employer because she complained of sexual harassment. ${ }^{26}$ The statutory formula, in principle, accommodates this scenario. The difficulty lies in the remedy. She may lose money because of her husband is no longer earning, but it will not be as much as the husband loses, something for which she cannot claim. The same logic applies to any distress caused. As such, this cannot provide a complete remedy.

\section{(ii) Recommendation}

In addition to compensation, employment tribunals may make recommendations, "for the purpose of obviating or reducing the adverse effect of any matter" that relates to the claimant or the workforce. ${ }^{27}$ This final phrase, introduced for the first time by the Equality Act 2010, permits tribunals to make recommendations relating to any deterrent effect of the employer's act. Thus, where say, a wife is suing for sexual harassment, and then for the victimisation of her husband, she may get recommendation that the husband is not to be victimised because of his wife's principal action for sexual harassment. This may mean, as the facts dictate, that the employer has to supply a job reference, or supply an accurate one, or provide the promotion or pay rise that was withheld in retaliation. However, this will not always provide a complete remedy. In the event of a dismissal, tribunals have been notoriously reluctant to order reemployment in parallel claims of unfair dismissal. ${ }^{28}$ A claimant would have another hurdle in distinguishing that established approach, especially in such acrimonious circumstances likely in these "vengeance" cases.

What is clear is that even the most generous tribunal could not "make whole" 29 the husband's loss, and so could not represent a full and proper implementation of the anti-victimisation principle in third-party cases.

(iii) Exemplary damages

Perhaps another way to "make whole" the husband's loss is to award the principal complainant exemplary damages. Exemplary damages are not compensatory, but instead are to deter and punish the defendant. Three categories were identified by Lord Devlin in Rookes $v$ Barnard. ${ }^{30}$ The first is oppressive, arbitrary, or unconstitutional behaviour by government servants. ${ }^{31}$ The second category arises where the defendant calculated that his conduct would make him a profit exceeding any compensation he would have to pay. This can apply to private defendants. The third is where exemplary damages are expressly authorised by statute (at present the discrimination legislation does not do this). ${ }^{32}$

The only reported cases where exemplary damages were awarded in a discrimination claim were City of Bradford Metropolitan Council v Arora, ${ }^{33}$ and Ministry of Defence v Fletcher. ${ }^{34}$ These cases fell under the first category. The third party victimisation cases are better suited to the second category. Of the second category, Lord Devlin said:

Where a defendant with a cynical disregard for a plaintiff's rights has calculated that the money to be made out of his wrongdoing will probably exceed the damages at risk, it is necessary for the law to show that it cannot be broken with impunity. 35 
Lord Devlin added that this is not confined to "moneymaking", but extends to seeking a gain of some object at the expense of the claimant. Although no discrimination cases have been heard under this second category, there are examples by analogy in tort. In Design Progression $v$ Thurloe $e^{36}$ a landlord was ordered to pay $£ 25,000$ for delaying (for financial gain) in consenting to the assignment of a lease, in breach of the Landlord and Tenant Act 1988, s.1(3) (a statutory tort). The award was to "mark the court's disapproval" and "cause the defendant to consider seriously its future conduct". ${ }^{37}$ And in Drane v Evangelou, ${ }^{38}$ a landlord was ordered to pay $£ 1000$ to an unlawfully evicted tenant for trespass.

In third party victimisation cases, the employer commits a statutory tort (the "wrongdoing") by victimising the principal claimant using her loved one, relative, or friend. The tangible harm done to the claimant is likely to be the distress, the deterrent effect, and perhaps pecuniary loss caused by a spouse and/or principal household earner losing his or her job. In so acting, the employer is trying to profit (or at least avoid a loss), and/or obtain some other object, by pressurising her into dropping her complaint. And even if the employer's act failed to deter the claimant, an award would make the employer (and other employers) "consider seriously its future conduct". The parent Directives appear ambivalent towards exemplary damages, providing that sanctions "must be effective, proportionate and dissuasive". 39 It is arguable that damages should be "proportionate" to the claimant's loss. But it is equally arguable that to be "dissuasive" an award could include exemplary damages.

However, awards of exemplary damages are by no means certain in English law, and even less so in discrimination cases. In the most recent House of Lords case to discuss the matter, Kuddus $v$ Chief Constable of Leicestershire Constabulary, ${ }^{40}$ the speeches were equivocal over the merit and status of exemplary damages. Whilst generally endorsing and developing the remedy, Lord Nicholls noted it was one "of last resort". 41 Lord Mackay stated that exemplary damages should not be awarded in discrimination cases unless expressly authorised by statute, ${ }^{42}$ whilst Lord Hutton preferred to reserve his opinion on discrimination until the matter came before him. ${ }^{43}$ Lord Scott said he would be "receptive" to an argument that that exemplary damages in civil cases should be abolished. ${ }^{44}$ A further uncertainty is their calculation, which is not subject to "nice legal principles" $"$ or "weighed in nice scales". 46 The only guidelines suggest that it should not matter if the defendant's wrongful act did not produce the desired effect (in this case deterring the claimant from pursuing the complaint), because the main purpose is to deter future wrongful conduct. The award must be "moderate", and not "excessive". Otherwise, the award is calculated "to mark the displeasure of the court". 47 Third party victimisation is certainly apt for exemplary damages. But the equivocation over the existence of such damages in discrimination cases, and to a lesser degree, over their calculation, does not provide a sound, reliable, predictable legal remedy for third party victimisation.

\section{B. The Victim Sues}

\section{(i) Third Party Discrimination}

Another tempting solution is to develop the seemingly elastic concept of "association discrimination", which is a form of discrimination on the ground of a third party's protected characteristic. The extensive reach of this notion was highlighted in a case concerning direct discrimination and harassment. In Coleman v Attridge Law ${ }^{48}$ the ECJ held that abusing and badly treating a worker because of her child's disability amounted to harassment of, and discrimination against, the worker, even though she had no disability: the conduct was on the ground of disability, and that was enough. By way of analogy, should not the victim of third party retaliation be able to sue because of his association with the principal complainant? The obvious objection is that the statutory definition of victimisation is not as facilitating as the harassment and direct discrimination formulas. As noted above, it specifies that the principal complainant and the victim are the same person. It now becomes tempting to stretch the Coleman principle of discrimination to cover these third party victimisation scenarios. For instance, where a white woman is dismissed because of her black husband's racial discrimination complaint, is she not suffering in much the same way as Ms Coleman? The difficulty with this approach is that it would in fact encompass all victimisation claims, and so leave the victimisation provisions stranded with no purpose. An interpretation that renders a section redundant should not stand.

Coleman is useful in this context to illustrate that third party victimisation is - conceptually - no more ground-breaking than the established notion of third party discrimination. Thus, "association discrimination" may prove influential, but it offers no immediate solution for a third party victimisation claim.

\section{(ii) Unfair Dismissal}

Where the retaliation amounts to a dismissal, a seemingly obvious alternative claim would be for unfair dismissal. Again, here the actual victim is suing. It is most unlikely that an employer could argue that a dismissal - taken out of vengeance, or to deter the principal complainant, or others - was fair. The limits to this remedy are where: the victim does not have the requisite one year's qualifying service, the claim exceeds the statutory cap, ${ }^{49}$ the claim 
includes injury to feelings, ${ }^{50}$ or of course, where the treatment falls short of dismissal. In these cases, an unfair dismissal claim will not be available, or where it is, it will provide an incomplete remedy.

Whilst these alternatives show that with some imagination, tribunals have it within themselves to address third party victimisation, the theories and remedies are either uncertain or incomplete, or both. Thus, we must look further afield for a solution.

\section{EU LAW}

The parent equality Directives are the Race Directive, the "Framework" Directive (covering religion or belief, sexual orientation, disability, and age), and the "Recast" Gender Equality Directive. The history of their victimisation formulas can be traced to Coote $v$ Granada, ${ }^{51}$ although they were not drafted expressly to address the deterrent mischief, nor the chilling effect and third party victimisation.

\section{Race Directive 2000/43/EC $\mathrm{E}^{52}$}

Preamble: (20) The effective implementation of the principle of equality requires adequate judicial protection against victimisation.

\section{Article 9}

Victimisation

Member States shall introduce into their national legal systems such measures as are necessary to protect individuals from any adverse treatment or adverse consequence as a reaction to a complaint or to proceedings aimed at enforcing compliance with the principle of equal treatment.

The Framework Directive ${ }^{53}$ contains the same Recital in its preamble, but the formula is couched in more restrictive terms:

Member States shall introduce ... measures as are necessary to protect employees against dismissal or other adverse treatment by the employer as a reaction to a complaint within the undertaking or to any legal proceedings aimed at enforcing compliance with the principle of equal treatment.

The formula in the Recast Directive ${ }^{54}$ is substantially the same.

Although not expressed to do so, the Race Directive's formula is broadly expressed and open enough to cover all three Classes of the third party victimisation scenarios. ${ }^{55}$ It requires adverse treatment as a reaction to a discrimination complaint or proceedings. There is nothing else limiting in this formula. But this openness could be explained by the Directive's reach, which covers areas beyond employment, such as the provision of goods and services. This becomes apparent upon reading the other equality Directives, which are confined to employment matters. The Framework and Gender Directives share a common, but narrower, formula. This readily covers the first two Classes, but not the third.

With these limits, the ECJ - and indeed domestic tribunals - may need convincing to identify the underlying principles to the victimisation provisions. As such, they may look further afield for influences and guidance. The possibilities include the law of the United States, the European Convention on Human Rights, the International Labour Organisation, European Social Charter, and the EU Charter of Fundamental Rights, as well and the EU's general principles of effective judicial protection and equality.

\section{A. The United States Experience}

There are many reported cases of third party victimisation the United States, where the courts face the same narrowly drafted statutory formula, which specifies that the victim and claimant should be the same person. The "retaliation" provision of the Civil Rights Act 1964, Title VII, prohibits less favourable treatment of a worker "because he has..." opposed discrimination or participated in discrimination proceedings. ${ }^{56}$ Although there appears to be a consensus around the deterrent mischief (see above), ${ }^{57}$ the Federal Circuits are split over third party victimisation. Some have taken a purposive approach recognising victimisation against someone "so closely related to or associated with the [plaintiff] ... that it would discourage that person from pursuing [her claim]". 58 It is upon this basis that the Federal enforcement body, the Equal Employment Opportunity Commission's Compliance Manual supports the recognition of third party victimisation. ${ }^{59}$ Courts have found liability where a wife was refused a job because her husband "agitated against discrimination", 60 or where a husband was fired because of his wife's complaint of sexual harassment. 61

But other US courts take the literal approach and do not recognise such claims, for instance, where a worker's partner was refused a promised return from maternity leave because he had made complaints of racial harassment. ${ }^{62}$ There are yet no reported cases in the UK. This disparity in reported incidents is probably explained 
by the fire-at-will doctrine prevalent in the US, where there is little or no protection against unfair dismissal. Some US courts fear that recognising third party victimisation would put an abnormal duty on employers to justify dismissals, save a dismissed worker suddenly claims to be somehow connected with the principal complaint. ${ }^{63}$ This is not to say that the problem of third party victimisation does not exist in the UK, as unfair dismissal is far from a complete remedy, as noted above.

The lesson from these cases is that it is possible distort a statutory formula in order to achieve the statutory purpose, in this context, recognising actions that would deter workers from complaining about discrimination. This is common practice under the Civil Rights Act 1964, and occasionally practised in the UK, although mainly under the authority of EU law. The resistance in the US to this approach is rooted, it seems, in deference to the fire-at-will doctrine, which of course is much less prevalent in the UK and the EU.

\section{B. International Charters and Conventions}

Of the social and economic instruments, the equality provisions provide nothing specific for third party victimisation, whilst those addressing unjustified dismissal are equivocal in their status and/or application. The International Labour Organisation's Convention 158 on unjustified dismissal is heavily qualified and has been adjudged to allow qualification or "probation" periods of at least one year, as well as limits on awards. ${ }^{64}$ The same is true of the EC's Charter of Fundamental Rights, Article 30, which prohibits unjustified dismissal, but only "in accordance with Community law and national laws and practices", which takes it no further than the existing domestic provisions for unfair dismissal. Further, the UK has not ratified C158, and "opted out" of the Charter. ${ }^{65}$ Article 24 of the European Social Charter (the social and economic companion to the European Convention on Human Rights) is unequivocal in its application, recognising "day-one" unfair dismissal rights ${ }^{66}$ and full compensation, ${ }^{67}$ but again has an equivocal status, as it has not been ratified by the UK.

Perhaps the most surprising candidate with the potential to recognise third party victimisation is Article 8, of the European Convention on Human Rights (ECHR), with provides the right to privacy. Here, the European Court of Human Rights and the House of Lords has held that an exclusion from a chosen career, or a "large sector of the job market" could interfere with one's ability to establish and develop human relationships and with it one's private life. $^{68}$ In some rare cases, a dismissal from a job in a particularly narrow profession, and/or with stigma (e.g. by association with a "troublemaker") could have that effect.

It would seem that a court - be it the ECJ or an employment tribunal - can draw little of substance from the international documents, although Article 8, ECHR, may offer a solution in some rare instances.

\section{General Principles of EU Law}

The development of the victimisation provisions in the equality Directives are underpinned by two complimentary principles relevant here. First, the prohibition of deterrents to workers using the discrimination legislation (Coote). ${ }^{69}$ Second, remedies must be sufficient to deter employers from discriminating (Marshall), ${ }^{70}$ or be "dissuasive", as the discrimination Directives instruct with their "Sanctions" articles. "It was noted above that the wording of the victimisation provisions in these Directives (save perhaps the Race Directive) is not broad enough to cover all the third party scenarios, notably those involving a second employer. What is required is an overarching general principle which is not bound by the niceties of the legislative formulas.

In 1986, the ECJ in Johnston $v$ RUC ${ }^{72}$ expressed the view that Equal Treatment Directive 76/207/EEC (ETD), ${ }^{73}$ Article 6 (effective remedy) "reflects a general principle of law". 74 We then saw Coote building on Johnston and Article 6 to establish the now-familiar rubric prohibiting victimisation, expressed in the discrimination Directives. Johnston and Coote concerned access to Court. Marshall built upon Article 6 to provide access to a full remedy. ${ }^{75}$ Finally, in Francovich, ${ }^{76}$ the ECJ created a new cause of action in order to provide an effective remedy under EC law. 77

What becomes apparent is that Article 6 (ETD), the deterrent mischief expressed in Coote and Marshall, the "dissuasive" principle, and prohibitions against victimisation in the discrimination Directives, are merely specific expressions of a general principle of judicial protection. ${ }^{78}$ As such, their precise wording should not restrict the general principle. That would be the tail wagging the dog. Quite clearly, if third party victimisation can occur without redress, or with only partial redress, the claimant is deterred from seeking a remedy and the employer is not dissuaded from intimidating her. This applies equally across all the scenarios. Thus, this general principle provides the most solid ground for a remedy to all three Classes of third party victimisation.

Thus, the victim should be permitted to sue, even if this means creating a new cause of action (Francovich). For some reason the victim may not sue. This may occur where, for example, the employer merely threatens to dismiss the claimant's spouse, should the claimant not abandon her claim. Here, principal claimant should be able to sue her employer and claim damages enough to dissuade the employer. ${ }^{79}$

Just as the victimisation and sanctions provisions are expressions of the general principle of effective judicial protection, there are expressions of the general principle of equality. This simply reinforces the importance 
of the equality principle, and with it, its enforcement. This can only be achieved by addressing the mischief of the deterrent effect. In Swedex, ${ }^{80}$ the ECJ relied on this principle to hold that the Framework Directive should be enforceable between private parties.

\section{CONCLUSION}

Quite clearly, the victimisation provisions ought to cover the deterrent effect, the chilling effect, and third party victimisation. It is equally clear that the domestic version falls short of this. The alternative solutions of remedies for the principal claimant, or alternative cause of action for the victim, are either inadequate or uncertain, or both.

The solution lies in EU jurisprudence. With the purpose of the Directives in mind, there are a number of factors which would push the ECJ towards recognising these claims. First, the general principle of judicial protection, which is broad enough to create a new cause of action if necessary. This factor alone should be enough. Second, the twin principles already associated with enforcement of removing deterrents to complainants and potential complainants (the chilling effect), and dissuading employers from intimidating them. Third, the recognition of third party victimisation is - conceptually - no more ground-breaking than the already recognised third party discrimination and harassment (Coleman). Fourth, when faced with the issue, some United States Federal Courts have taken a purposive approach (and the restrictive approach by other US courts could be explained by the fire-at-will doctrine). Fifth, in principle, third party victimisation can amount to common law contempt (expressly recognised by the Criminal Justice and Public Order Act 2001). Last, there is potential in Article 8 (ECHR) jurisprudence to cover some cases. Other potential influences - the international Charters and Conventions mentioned - are, at best, equivocal on the issue and in their status.

It is clear, that to address third party victimisation, a new definition of victimisation is required with this express purpose. The obvious solution is to rephrase the domestic formula to read "and does so by reason that $a$ person has [done a protected act]". This still requires a causal link ("because") between the protected act and the unfavourable treatment, and so this open formula should not fall prey to a number of meritless claims.

\footnotetext{
${ }^{1}$ NLRB v Advertisers Manufacturing Co 823 F. 2d 1086, 1088 (7th Cir. 1987).

${ }^{2}$ See e.g. Hashimoto v Dalton 118 F 3d 671 ( $9^{\text {th }}$ Cir 1997) certiorari denied 523 US 1122 (Sup Ct 1998), below, text to n.13. Cf Chief Constable of West Yorkshire v Khan [2001] I.C.R. 1065 (HL), as explained in St Helens BC v Derbyshire [2007] I.C.R. 841 (HL), [68]. For a discussion of the harm principle, the chilling effect, and victimisation, see "Rethinking Victimisation" (2009) 38(2) I.L.J. 149179 , at $165-172$.

${ }^{3}$ Or the defendant believed he did, or will do, it.

${ }^{4}$ See below, text to $n .24$.

${ }^{5}$ Race Directive 2000/43/EC; Framework Directive 2000/78/EC (religion or belief, sexual orientation, age, disability); Recast Directive 2006/54/EC (sex and gender reassignment).

${ }^{6}$ Case C-185/97, [1998] E.C.R. I-5199.

${ }^{7} \mathrm{Ibid},[24]$.

${ }^{8}$ Communication from the Commission to the Council and the European Parliament, "The application of Directive 2000/43/EC of 29 June 2000 implementing the principle of equal treatment between persons irrespective of racial or ethnic origin.” COM/2006/0643 final, para.2.

${ }^{9}$ Ibid, $\$ 3$.

${ }^{10}$ Commission (EC), "Proposal for a Council Directive Establishing a General Framework for Equal Treatment in Employment and Occupation”. COM/99/0565 final CNS 99/0225 Explanatory Memorandum, 5. Explanation of Individual Articles of the Proposed Council Directive, Article 10. ${ }^{11} 519$ US 337 (1997).

${ }^{12}$ Ibid, 345-346. Cited by the Supreme Court more recently in Burlington Northern $v$ White $126 \mathrm{~S}$. Ct. 2405 (Sup. Ct. 2006), where the majority stated that for liability the victimisation must have been such that it "dissuaded a reasonable worker from making or supporting a charge of discrimination." (At 2415, quoting from Washington v Illinois Department of Revenue, 420 F 3d 658, 662). In CarmonaRivera v Commonwealth of Puerto Rico 464 F 3d 14, 20 (2006), the $1^{\text {st }}$ Circuit took this "reasonable worker" to include other workers. After citing White the court observed: "In addition, there is little indication that the actions of the defendants would have the chilling effect of deterring others". 13118 F 3d 671 ( $9^{\text {th }}$ Cir 1997) certiorari denied 523 US 1122 (Sup Ct 1998). See $\mathrm{n} * 95$.

${ }^{14} \mathrm{Ibid}, 676$. This is also the view of the Federal enforcement commission, the Equal Employment Opportunity Commission: 2 EEOC Compliance Manual §8, 8-12,13 (1998). The Supreme Court has adopted the EEOC's definition: Burlington Northern v White 126 S. Ct 2405, 2415 (Sup Ct 2006).

${ }^{15} \mathrm{Ibid}, 677$ : the order upheld was to (1) cease the practice of notifying prospective employers of its employees' or former employees' participation in protected activities; (2) remove from Hashimoto's personnel files the negative character reference; (3) provide equal opportunities training to all
} 
supervisory staff; and (4) post copies of an EEOC notice throughout the camp. See further, cases cited within, ibid 677-678.

${ }^{16}$ In Cornelius v University of Swansea [1987] I.R.L.R. 141 (CA), at p.145, Bingham, L.J. observed that the victimisation provision had an "obvious although partial analogy to the law of contempt".

${ }^{17}$ The Contempt of Court Act 1981, which applies strict liability, applies only to publications.

18 There are examples of individuals with sufficient interest instigating contempt proceedings with punishment as the goal: Connolly v Dale [1996] Q.B. 120 (Q.B.), at 125; Raymond v Honey [1983] 1 A.C. 1 (HL); In Re the William Thomas Shipping Company [1930] 2 Ch 36 (Ch).

${ }^{19}$ For an argument that the victimisation found in St Helens BC v Derbyshire Helens BC v Derbyshire [2007] I.C.R. 841 (HL) amounted to contempt, see "Reinterpreting Khan- Easy case Makes Bad Law" (2008) 36 I.L.J. 364-374, 372.

${ }^{20}$ Civil Procedure Rules 1998 S.I. 1998/3132, Sch 1, Part 52, Rule 1(2)(a)(iii); Peach Grey v Sommers [1995] I.C.R. 549 (Div Ct) 557-559; Harris (Andrews) v Lewisham \& Guy's NHS Trust [2000] I.C.R. 707 (CA), [17], [32].

${ }^{21}$ CJPO Act 2001, s.39(6).

22 [2009] EWCA Crim 2616.

${ }^{23}$ Ibid, [27]-[30].

${ }^{24}$ Attorney-General's Reference (No. 1 of 1999) [2000] 1 Q.B. 365 (CA), at 372 (Henry, L.J.) citing Archbold, Criminal Pleading, Evidence \& Practice, 1999 ed., p. 2299, para. 28-148.

${ }^{25}$ CJPO Act 2001, s.41.

${ }^{26}$ This would require subtle and nuanced presentation of the evidence. See the US case Probst $v$ Reno 917 F. Supp 554 (ND Ill, 1995).

${ }^{27}$ EA 2010, s.124. This has always been available in under Northern Ireland's Fair Employment and Treatment Order, 1998, Art 39(1)(d). See also in the US: Civil Rights Act 1964, s.706(g)(1), USC $\S 2000 \mathrm{e}-5(\mathrm{~g})(1)$.

${ }^{28}$ See e.g. Deakin and Morris, Labour Law (4 ${ }^{\text {th }}$ ed. Hart, Oxford, 2005), para 5.152.

${ }^{29}$ See comment in De Medina $v$ Reinhardt 444 F. Supp 573 (DDC, 1978), 580.

${ }^{30}$ Rookes $v$ Barnard [1964] A.C. 1129, at 1226-1227 (HL).

${ }^{31}$ Cassell v Broome [1972] A.C. 1027 (HL), at 1077-1078, 1130, 1134.

${ }^{32}$ The Equality Act 2010 does not alter this position.

${ }^{33}$ [1991] 2 Q.B. 507. Overruled by AB v South West water Services [1993] Q.B. 507(CA), but restored by Kuddus v Chief Constable of Leicestershire Constabulary [2002] 2 A.C. 122 (HL)). In Newcastle upon Tyne CC v Allan [2005] I.C.R. 1170 (EAT) [12], Burton, P. suggested obiter, that Kuddus "could found an argument" for recovering exemplary damages under the Sex Discrimination Act 1975.

${ }^{34}$ [2010] I.R.L.R. 25 (EAT).

${ }^{35}$ Rookes $v$ Barnard [1964] A.C. 1129, at 1227 (HL).

${ }^{36}$ [2005] 1 W.L.R. 1 (Ch D).

${ }^{37} \mathrm{Ibid},[150]$.

${ }^{38}$ [1978] 1 W.L.R. 455 (CA).

39 2000/43/EC, Art 15; 2000/78/EC, Art 17; 2006/54, Recital (35), Arts 18 \& 25.

${ }^{40}$ [2002] 2 A.C. 122.

${ }^{41}$ Ibid, [63].

${ }^{42}$ Ibid, [46].

${ }^{43}$ Ibid, [92].

${ }^{44} \mathrm{Ibid},[111]$.

${ }^{45}$ Design Progression v Thurloe [2005] 1 W.L.R. 1 (Ch D) 30.

${ }^{46}$ Drane v Evangelou [1978] 1 W.L.R. 455 (CA) 459 (Lord Denning MR).

${ }^{47}$ Design Progression v Thurloe [2005] 1 W.L.R. 1 (Ch D) [146]-[148].

${ }^{48}$ Case C-303/06 [2008] I.R.L.R. 722 (ECJ). See also Showboat Entertainment Centre v Owens [1984] 1 All E.R. 836 (EAT) (white manager dismissed for disobeying order to ban black youths); Weathersfield (t/a Van \& Truck Rentals) v Sargent [1999] I.C.R. 425 (CA) (white worker (constructively) dismissed following instruction not to hire vehicles to "coloured and Asians").

${ }^{49}$ At present, £65,300: Employment Rights (Increase of Limits) Order 2008, S.I. 2008/3055 as amended, from $1^{\text {st }}$ October 2009, SI 2009/1903.

50 "An award of damages may include compensation for injured feelings (whether or not it includes compensation on any other basis)": EA 2010, 119(4), which applies to employment tribunals via 124(6). Damages for injury to feelings are not available in unfair dismissal claims: Dunnachie v Kingston-upon-Hull City Council [2004] UKHL 36.

${ }^{51}$ Case C-185/97, [1998] E.C.R. I-5199. Above, text to n.6. 
${ }^{52}$ [2000] OJ L180/22.

${ }^{53}$ 2000/78/EC [2000] OJ L 303/16, Art.11.

${ }^{54}$ 2006/54/EC [2006] OJ L 204/23, Art.24

${ }^{55}$ Set out in the Introduction, above.

${ }^{56}$ S. 704 (42 USC § 2000e-3). Emphasis supplied.

${ }^{57}$ Text to n. 11

${ }^{58}$ See Thompson v NA Stainless 520 F. 3d 644 (6th Cir, 2008).

${ }^{59}$ EEOC Compliance Manual $\$ 8006$. The EEOC's interpretations "enjoy great deference": McDonald $v$ Santa Fe 427 U.S. 273, at 279 (1976); United States v City of Chicago 400 U.S. 8 (1970); Griggs v Duke Power 401 U.S. 424, at 433 (1971).

${ }^{60}$ De Medina v Reinhardt 444 F. Supp 573 (DCDC 1978) (appealed on other grounds: 686 F. 2d 997).

${ }^{61}$ McKenzie v Atlantic Richfield 906 F. Supp 572, 575 (D Colo, 1995).

${ }^{62}$ EEOC v Bojangles, 284 F. Supp 2d 320, 324 (MDNC 2003); See also Holt v JTM Industries 89 F. 3d 1224 (5th Cir, 1996) (H put on leave and transferred following W's age discrimination claim).

${ }^{63}$ See e.g. Fogleman v Mercy Hospital 283 F. 3d 561, 569-570 ( $3^{\text {rd }}$ Cir. 2002), and the concurring Opinion of Alito, J. in the Supreme Court: Crawford v Metropolitan Government of Nashville 129 Sup Ct 846, 853-855 (2007)

${ }^{64}$ See respectively: Report of the Committee of Experts, adopted by the International Labour Conference, 82nd Session 1995, as Report III (Part 4B)) "Ch II Scope of the instruments as regards individuals", para 42, citing 10 years (Canada, Nova Scotia), three years (Canada, Quebec), two years (UK, at the time), one year (Sri Lanka). < www.ilo.org/ilolex/english/surveyq.htm > accessed 12 April 2010; Report of the Committee of Experts, adopted by the International Labour Conference, 82nd Session 1995, as Report III (Part 4B)) "Chapter IV. Procedures relating to termination of employment", paras.232 and 229. < www.ilo.org/ilolex/english/surveyq.htm > accessed 12 April 2010.

${ }^{65}$ Protocol on the Application of the Charter of Fundamental Rights of the European Union to Poland and to the United Kingdom [2007] OJ C 306/156 EN. On the substance of the "opt out", see House of Lords European Union Committee, "Tenth Report", HL (2007-2008) 62-I, Ch 5, especially [5.84][5.111]; see also Sypris, "The Treaty of Lisbon: much ado...but about what?" (2008) 37(3) I.L.J. 219, at 231-234.

${ }^{66}$ See Committee of Social Rights reports on e.g. Italy (2007), Malta (2008), Cyprus (2008), and the (notorious) French Contract of New Employment (imposing a two-year qualification period for those employed by businesses with not more than 20 workers) (2008)

<http://hudoc.esc.coe.int/esc2008/query.asp?language=en> accessed 21 April 2010.

${ }^{67} \mathrm{Ibid}$, respectively Bulgaria (2008), Albania (2008), Finland (2007).

${ }^{68}$ See e.g. Sidabras v Lithuania (App No 55480/2000) (2006) 42 E.H.R.R. 6, [48]-[49]; $R$ (on the application of L) v Metropolitan Police Commissioner [2009] UKSC 3, [24], [70]; $R$ (on the application of Wright and others) v Secretary of State for Health [2009] UKHL 3, [2009] 2 All E.R. 129 (HL), [36].

${ }^{69}$ Case C-185/97, [1998] E.C.R. I-5199. Discussed above, text to n.6.

${ }^{70}$ Case C-271/91 Marshall v Southampton and South West Hampshire AHA (No 2) [1993] E.C.R. I4367, [24].

71 "The sanctions, which may comprise the payment of compensation to the victim, must be effective, proportionate and dissuasive": 2000/43/EC, Art 15;2000/78/EC, Art 17. See also the slightly differently worded Recast Directive 2006/54, Recital (35), Arts 18 \& 25.

${ }^{72}$ Case 222/84 (1986) E.C.R. 1651.

${ }^{73}$ The predecessor to the Recast Directive 2006/54/EC.

${ }^{74}$ Case 222/84 (1986) E.C.R. 1651 [18]-[19]: "The requirement of judicial control stipulated by [Art 6] reflects a general principle of law which underlies the constitutional traditions common to the Member States. That principle is also laid down in Articles 6 and 13 of the ECHR ... By virtue of Art $6 \ldots$ interpreted in the light of the general principle stated above, all persons have the right to obtain an effective remedy in a competent court against measures which they consider to be contrary to the principle of equal treatment for men and women laid down in the Directive".

${ }^{75}$ Case C-271/91 [1993] E.C.R. I-4367, [24].

${ }^{76}$ Case C-6/90 Francovich v Italian Republic [1991] E.C.R. I-05357.

${ }^{77} \mathrm{Ibid}$, [33]-[37]. See generally, Drake, "Scope of Courage and the principle of "individual liability" for damages: further development of the principle of effective judicial protection by the Court of Justice" (2006) 31(6) EL Rev 841-864; Szyszczak "European Community Law: New Remedies, New Directions" (1992) 55(5) M.L.R. 690-697; Fitzpatrick and Szyszczak, "Remedies and Effective Judicial Protection in Community Law" (1994) 57(3) M.L.R. 434-441. 
${ }^{78}$ Expressed in TEU, Art 19, CFR, Art 47. See also Case C-63/08 Pontin v T-Comalux SA [2009] E.C.R. I-10467, [41]-[42]: "Those provisions, and in particular Article 12 of Directive 92/85, constitute a specific expression, in the context of that directive, of the principle of effective judicial protection of an individual's rights under Community law. ... although the Member States are not bound under Article $12 \ldots$ to adopt a specific measure, nevertheless the measure chosen must be such as to ensure effective and efficient legal protection, must have a genuine dissuasive effect with regard to the employer and must be commensurate with the injury suffered..."; Case C-317/08 Alassini v Telecom Italia SpA (2010) E.C.R. 000, [61]; Case C-432/05 Unibet [2007] E.C.R. I-2271, [37], and Joined Cases C-402/05 P and C-415/05 P Kadi and Al Barakaat International Foundation v Council and Commission [2008] E.C.R. I-6351, [335]. When drafting the Framework Directive, the Commission stated that "effective judicial protection must include protection against retaliation" (above, $\mathrm{n} 41$ ). ${ }^{79}$ Some adjustment of time limits and/or priority will be required here, to prevent duplication.

${ }^{80}$ Case C-555/07 Kücükdeveci v Swedex GmbH (2010) E.C.R. 0000, [2010] I.R.L.R. 346 (ECJ) [27], [50]-[51], following Case C-144/04 Mangold v Helm [2005] E.C.R. I-9981, [75]. 